\title{
WATERFRONT LANDSCAPES IN SPANISH CITIES: REGENERATION AND URBAN TRANSFORMATIONS
}

\author{
PABLO MARTII ${ }^{*}$ CLARA GARCÍA MAYOR ${ }^{\dagger} \&$ ANA MELGAREJO \\ Building Sciences and Urbanism Department, University of Alicante, Spain
}

\begin{abstract}
The process of regenerating and integrating urban water spaces, which converts them into valuable and attractive landscape elements, is a relatively recent phenomenon in Spanish cities. Seas, rivers and wetlands have traditionally been either a means of communication with an economic value or a hydraulic problem requiring management. The first expressions of this new relationship between water and cities date back to 1988, when the UR journal of the Urbanism Laboratory, Barcelona School of Architecture, in its second issue dedicated to the Urban Project, highlighted the transformation of Barcelona's port waterfront. Another important milestone occurred in the mid1990s when Urbanism journal - published by Madrid Architects' Association - launched a special issue on the port and river transformations of several Spanish cities that possessed a specific urban character. This issue included an influential article "Urban Ports. Transformation of dock areas in urban contexts", which revealed two important aspects of the urban role of water. First, a reference to Peter Hall who described the revitalization of waterfronts as the major event in urban planning in the $1980 \mathrm{~s}$ and compared them to the importance of motorways and new residential areas of the 1950s and 1960s. Second, the remodelling of port spaces for urban uses was described as one of the most interesting issues in urban planning in recent decades. These interventions provided a greater understanding of the territorial and urban context in which they were situated, incorporating, therefore, a better integration of the landscaping project. The selected sea and river waterfronts in this paper offer an overview of the urban and territorial strategies proposed for the Spanish cities. Several situations are chosen to demonstrate the variety of encounters between the city and water: the maritime fronts, the riverfronts and a case corresponding to lagoons or wetlands.

Keywords: urban waterfronts, urban regeneration, urban transformation, urban water strategy, Spanish waterfronts.
\end{abstract}

\section{INTRODUCTION}

Waterfronts are a city boundary and a multi-layered concept requiring a multidimensional approach. This paper deals with a number of interventions in different Spanish urban waterfronts [1] indicating a diverse range of strategies which ultimately serve the following common goals of providing a new urban spatial context, generating a new social role for these places by stimulating social interaction and a socially integrative city, and, finally, revaluing adjacent areas (both land and building value). Clearly, all these factors preserve and enhance a city's attractiveness, promoting new opportunities for urban and social development [2]. At the same time, these urban designs have regenerated obsolete areas, renewed infrastructures supporting sustainable mobility all of which promote attitudes to healthy lifestyles. Furthermore, these factors contribute to making city water boundary areas more appealing to businesses and investors, thereby improving the resilience of urban public space networks. This is evidenced by the increasing commercial, social and cultural activity in these areas in differently designed urban contexts.

The quality of public spaces in urban transformation projects is related to their design,

*ORCID: https://orcid.org/0000-0002-6877-784X

${ }^{\dagger}$ ORCID: https://orcid.org/0000-0002-7714-3363 
materials and maintenance as well as the derived social benefits but quality can also be understood in terms of the urban space's impact on the circular economy of cities.

There is a direct relationship between the urban tissue's value in social and economic terms and public space quality (design, materials, accessibility and maintenance). These aspects enable us to address urban transformation projects from the perspective of the circular economy. This paper claims that regenerating of waterfront public spaces in a city has a multiscale impact, including positive benefits to the circular economy [3].

\section{WATER AS A LANDSCAPE ELEMENT IN SPANISH MEDITERRANEAN CITIES}

The recovery of urban water landscapes in Spain over the last decades is reviewed in the following sections through representative or singular examples. Three types of waterfronts have been selected to showcase the threshold where city and water meet: maritime fronts, riverfronts and a specific case corresponding to lagoons or wetlands. All the cases reviewed (Fig. 1) are representative examples that reveal a wide variety of strategies through the projects developed. This diversity originates from different vocation as well as the scale of the urban spaces in question.

\section{SEA WATERFRONTS}

The selected maritime fronts offer a perspective of the urban and territorial strategies for the Spanish maritime cities classified into three cross-cutting sets (Table 1). The first group of cities is located in urban areas of a certain dimension and whose transformations have a clear metropolitan condition: Barcelona and Valencia. The second group focuses on two Mediterranean middle-sized cities with tourist vocation, such as Benidorm and Torrevieja. Finally, the third group gathers some examples of projects transformed into landmarks beyond the city waterfront.

\subsection{Barcelona and Valencia}

Barcelona and Valencia are the largest cities in population and size of the Spanish Mediterranean Arc area. These great metropolitan areas occupy the coastal plains and are articulated between the coastline and the inner mountain ranges. Historically, these maritime fronts have evolved from fishing harbour docks, located in proximity to the city with humble fishermen quarters nearby, to become one of the city's key landmarks in the urban tissue.

Table 1: Explanatory table of thematic categories and the selected cities.

\begin{tabular}{|c|c|c|}
\hline \multicolumn{2}{|c|}{ Water as the backbone of urban transformation in... } \\
\hline Sea waterfronts & River waterfronts & $\begin{array}{c}\text { Other waterfronts: } \\
\text { wetlands }\end{array}$ \\
\hline Barcelona & Madrid & Torrevieja \\
Valencia & Valencia & \\
Tourist cities & Zaragoza & \\
Benidorm & Bilbao & \\
Torrevieja & Elche & \\
Singular spots & & \\
San Sebastian & & \\
Fisterre & & \\
\hline
\end{tabular}




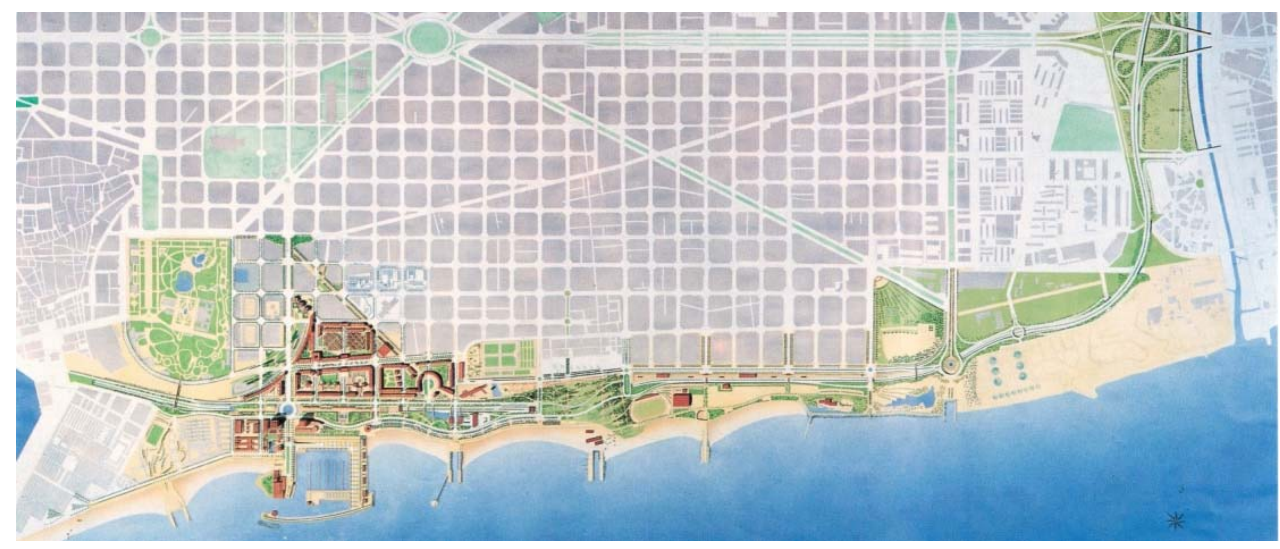

Figure 1: Urban interventions in the Barcelona waterfront on the occasion of the Olympic Games in 1992. (Source: Martorell et al. [5].)

\subsubsection{Barcelona}

The transformation of the maritime front of Barcelona (Fig. 1) is the first Spanish intervention and one of the most influential examples because of its huge impact on the transformation of the city's character. The first intervention for recovering the maritime front took place at the end of the 1980s at the Moll de la Fusta - the wood loading dock - designed by Manuel de Solà Morales [4]. This project offered a new relationship between the city and the sea, through a new public space at various levels.

The next stage in the transformation of the coast of Barcelona took place on the occasion of the Olympic Games in 1992. This intervention affected two kilometres of the city's north coastline and represented an important recovery of its waterfront. The transformation of industrial spaces, railways and other disused urban spaces into a new residential, commercial and leisure area completely changed the maritime vocation of Barcelona. In addition, the success of this new urban space [5] is demonstrated by the proposed urban and architectural project as well as how the change of use of this relevant fragment of the city was managed.

The last and most recent transformation was done in 2004, along the remaining three kilometres of the north coast. Once again, an international event, the Universal Forum of Cultures, provided the rationale for the transformation of the remaining coastline and its surroundings. On this occasion, new residential, commercial, and leisure spaces were also included in the complex configuration of this space [6].

\subsubsection{Valencia}

Although the city of Valencia has never been a maritime city, in the last decades the urban development of its coastline and the appropriation of the waterfront has been an important goal. One of the most comprehensive plans for the maritime metropolitan area of Valencia was the proposal named La Valencia Maritima del 2000 - The maritime Valencia in 2000 a plan developed by the Department of Urbanism at the Polytechnic University of Valencia [7]. This plan proposed a territorial balance in terms of economic activities and uses of land throughout the maritime space along the fifty kilometres of the metropolitan Valencian coastal area.

The proposal's starting point was in a context characterised by contradictory territorial realities of different scope and theme. 

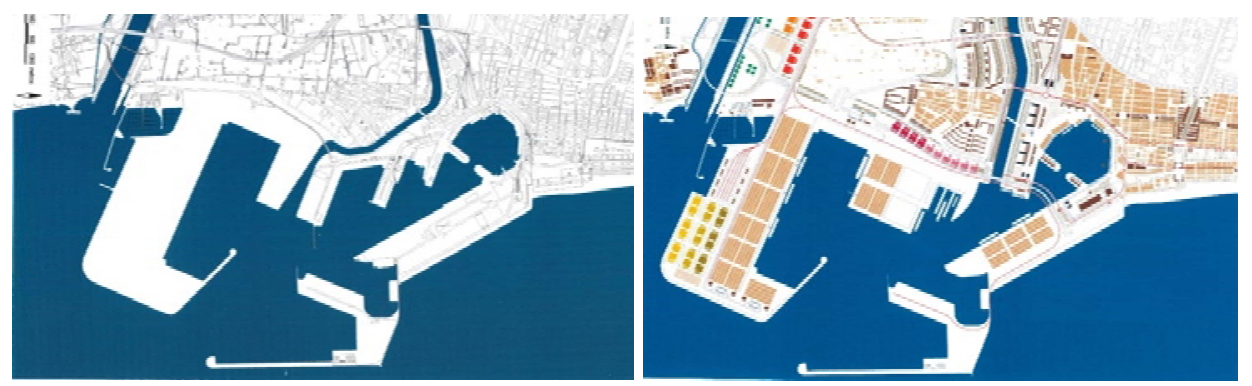

Figure 2: General plan and detailed proposals in Valencia. (Source: Pecourt and Piñón [7].)

Firstly, on a metropolitan scale, the unbalanced use of land in the northern and southern coastal areas serves as a constraint to the preservation of their environmental value. Secondly, concerning port activity, Valencia's harbour expansion was done at the expense of occupying ancient orchards known as Huertas; while the port of Sagunto, well connected and very near Valencia, was offering industrial and logistic vacant plots. And thirdly, at an urban level, Valencia had not developed its relationship with the maritime front and new demands were emerging for a better connection with the city's coastal space.

Thus, the project developed several strategies to tackle the aforementioned problems. At a metropolitan level, the proposal was to displace the intensive land use linked to leisure and vacation, from south to the north, reducing the accessibility and protecting certain areas. The south coast of Valencia is a space of undoubted environmental value, namely the Albufera lagoon, and the dunes and beaches of El Saler. By contrast, the north lacks the previous environmental value and has new potential areas linked to the maritime front as well as the possible development of new beaches located a few kilometres from the capital.

Also several interventions were planned for the city of Valencia in order to improve accessibility, linkage and the perception of the coastal space, such as, the creation of new inland accesses to the beach of La Malvarrosa, the transformation of the port space - creating new urban uses in the old port and docks - the continuity of the Turia river to the Mediterranean sea, the recovery of the lost coastal sea front in small residential districts Nazaret and Pinedo - and, a balanced distribution in the use of the huerta area for logistic uses linked to the port (Fig. 2).

\subsection{Tourist cities: Torrevieja and Benidorm}

Several tourist cities have transformed their waterfronts converting them into a relevant and valued tourist landmarks. Two emblematic middle-sized cities of the European tourist circuit in the province of Alicante can be mentioned: Benidorm and Torrevieja. In both cases, local governments decided to carry out major transformations of their waterfronts in order to regenerate the city's image.

\subsubsection{Benidorm}

In Benidorm Carlos Ferrater and Xavier Martí designed the Paseo Marítimo de la Playa de Poniente (Fig. 3) "west beach promenade" as a complex and three-dimensional element that permeates the transition from the built city to the beach and sea space. As a result of this innovative design, there has been a revitalization of the public space along this western promenade. 


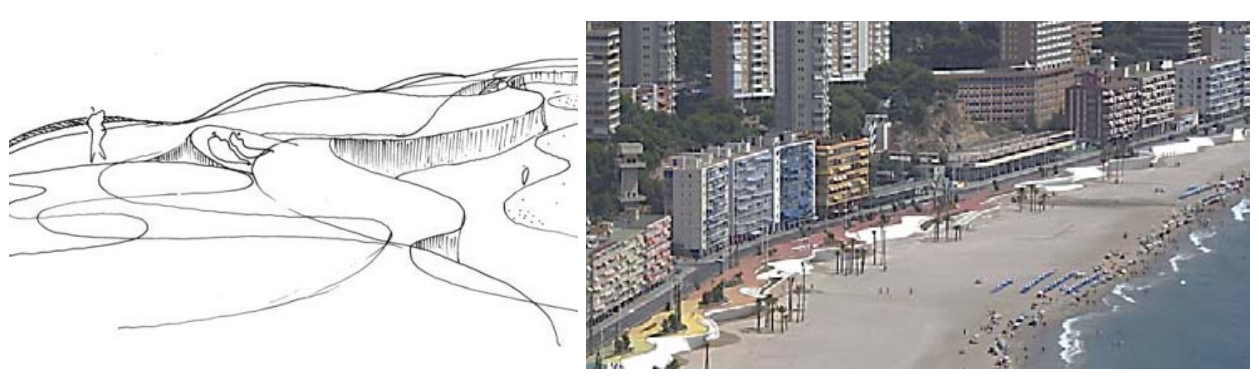

Figure 3: Seafront promenade of Poniente (west beach) in Benidorm. (Source: Office of Architecture in Barcelona (OAB) and Alejo Bagué (right).)

\subsubsection{Torrevieja}

In Torrevieja, Carme Pinós designed a new waterfront (Fig. 4) that limited road traffic to the harbour and transformed the existing space into a public space where the neighbours of Torrevieja can walk and meet, implementing vegetation and generating shaded zones [8]. Several artificial seawater swimming pools extend the promenade walkways into the Mediterranean Sea, beyond the coastline, broadening this public space and providing more complexity and interesting features to the urban scene.

\subsection{Singular spots: San Sebastian and Finisterre}

The following projects are landmarks located beyond the city at the waterfront. These are places of high environmental quality and where the architecture complements the environment through the creation of an artistic and contemplative experience. The artistic sculptures of San Sebastian, as well as the minimal architecture embedded in the natural context in Finisterre, provide a new perception of place. They have become additional landmarks which in turn creates new city tours.

\subsubsection{San Sebastián}

The first case, El Peine del Viento (The Comb of the Winds), completed in 1976 by the sculptor Eduardo Chillida and the architect Luis Peña Ganchegui, is an urban landscape intervention in the western end of the bay of La Concha in San Sebastián. An urban public

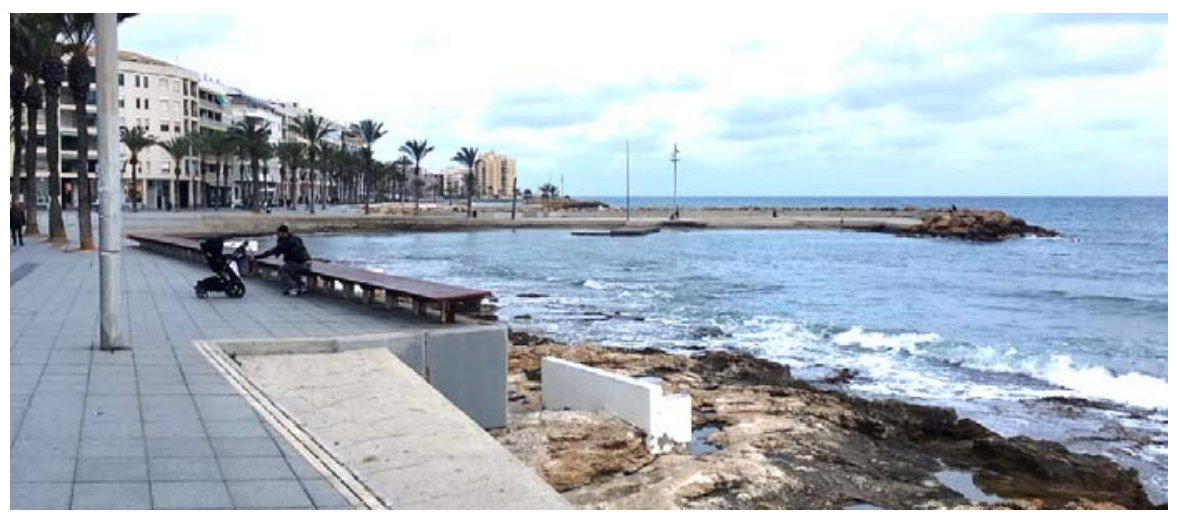

Figure 4: Seafront promenade in Torrevieja. (Source: Author's image.) 
area is created at the end of the coastal promenade, including a set of three steel sculptures embedded in the rocks and facing the Cantabrian Sea. The project constitutes a final landmark in the landscape of the maritime front.

The lookout platforms from which the sculptures are observed are adapted to the existing geography of the rocks by constructing several multilevel platforms with sharp geometrical lines between the sea and rocky cliff, providing a powerful contrast with the natural surroundings. In addition, Peña Ganchegui takes advantage of an existing water collector used in reverse direction, which allows the sea waves to flow under the observation platforms, expelling jets of water through several pavement gaps in the platform generating a complete sensory experience for the user.

\subsubsection{Finisterre}

The Finisterre cemetery in A Coruña is a landscape work by the architect César Portela, completed in 2000. This project is located on the mountainside and with the sea as a backdrop. The main challenge of the project is the location, in particular, two difficulties are evident. Firstly, to integrate the architecture in the territory. Secondly, to overcome traditional designs of Spanish cemeteries as closed, limited enclosures, introducing an alternative proposal which is a free and fragmented structure adapted to the natural characteristics of the site. The structure follows the topographical features of the slope, introducing a new access route which, at the same time, contributes to generate a new landscape visual tour following the natural coastline.

\section{RIVER WATERFRONTS}

The previous examples of waterfront projects provided a varied representation of the recovery of the Spanish maritime urban contexts. The transformations in river waterfronts offer a complementary view of the strategies and intentions developed along urban stretches of riverbanks which also represent a comprehensive regeneration of the city. Five cities have been selected to exemplify different approaches in terms of city scale and aims: Madrid, Valencia, Zaragoza, Bilbao and Elche. It must be highlighted that the promotion of each project has derived from a diverse way of proceeding: the city urban planning development, the celebration of an international event or holding a public competition. All the cases have in common some goals such as: improving connectivity between both sides of the river, mainly related to existing urban tissues; introducing complementary facilities that serve the city in a multiscale way; renew urban green corridors; or regenerate heritage features.

\subsection{Madrid Río, urban infrastructure redevelopment plan}

Historically, Madrid City neglected the Manzanares River as an important urban structural landmark for the city's expansion. The development of the M30 orbital motorway in 1974 provided a new means of connectivity from the periphery neighbourhoods to the city centre occupying both riverbanks but, at the same time, isolating the river from the urban tissue with an impenetrable and environmentally aggressive barrier.

The tunnelling of the M30 ring road - which lasted from 2003 to 2007 - gave Madrid City Council the opportunity to create new open spaces in the river area [9] with a renewal project which provided a new role for the river as an essential green connector in the city.

The proposed solutions for the construction of an urban park that would extend more than 120 hectares, occupying the new open space surface [9], was developed by Mrío Arquitectos Asociados and West8. 


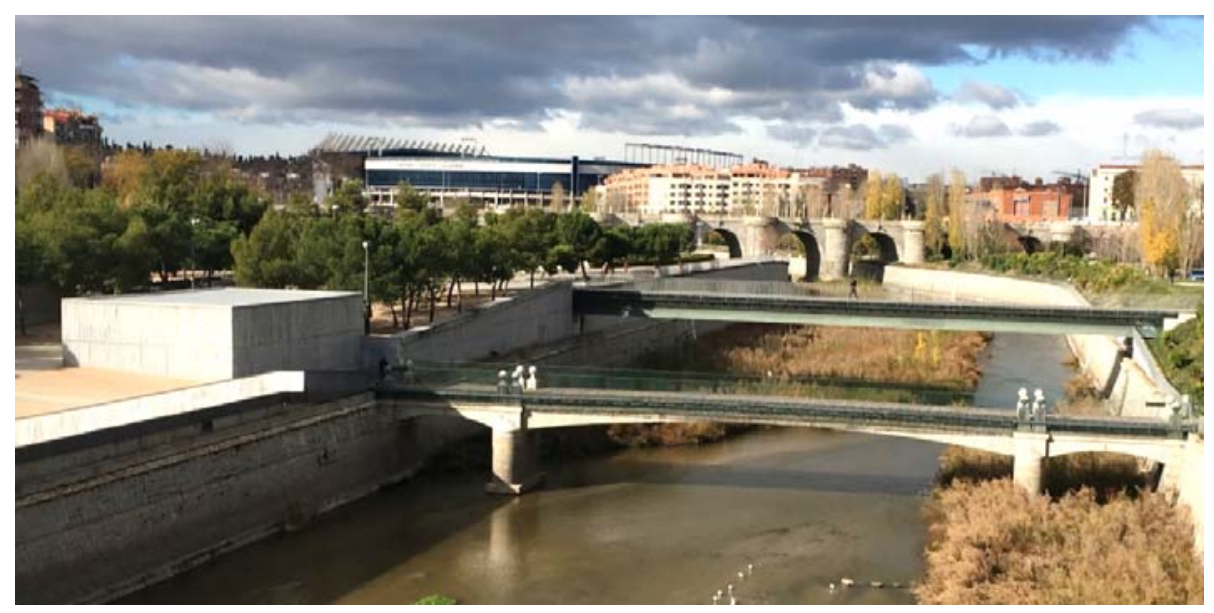

Figure 5: Madrid Río general view from the Arganzuela Bridge. (Source: Authors' image.)

Madrid Río is a 7-kilometre stretch located in the city centre, which connects the city's urban tissues from the 19th century Puente de los Franceses to the area known as the South junction. The proposed design is a multiscale project, from the territorial to the local, as well as from the strategical goals to the specific solutions.

Considering the urban scale, the river has a key role in providing an opportunity for the regeneration of the city's urban riverfront façade. The Manzanares corridor connects to other existing urban public spaces in the area (Fig. 5), linking green elements, improving mobility and accessibility, as well as the integration of surrounding neighbourhood urban tissues.

\subsection{The Turia River in Valencia}

The transformation of the original riverbed of the Turia River across the city of Valencia is a paradigmatic example of the change in the social perception of these spaces. Its development as an urban park would not have been possible if the society and public administrations had not changed their opinion of the river and its surroundings.

The first master city plan of the 20th century, in 1946, planned to channel the river and occupying the surface with residential buildings. Nevertheless, continuous flooding made this proposal unfeasible leading to a diversion of the river and building a new channel that would avoid floods. In 1967 the new Master City Plan proposed to occupy the old riverbed, with a new motorway that crossed the city from east to west (Fig. 6 (left)). The models and drawings showed a motorway with three lanes in each direction linking the existing road network, crossing the historical dock of the port and even encircling historical monuments from the 14th century, such as the Serrano Towers.

With the incorporation of democratic municipalities, in 1978, citizen demands dismissed the nonsense proposal. The Master City Plan of 1988 decided to transform the old riverbed into an urban park. Thus, the design by Ricardo Bofill defined a great green zone of almost ten kilometres in length and more than a hundred meters in width that crossed the whole city from the western end to the historical basin of the port of Valencia (Fig. 6 (right)). 

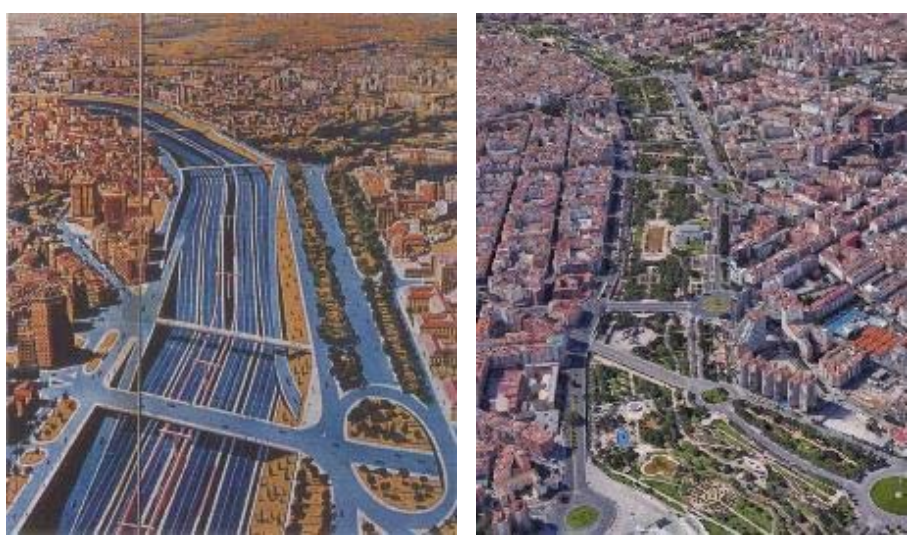

Figure 6: Aerial views of Turia River stretch. Left, 3D proposal of 1966 Valencia plan for Turia riverbed; Right, current configuration. (Sources: Gaja, F. [10]; Google Earth (right).)

\subsection{Zaragoza}

The Zaragoza Expo is an example of a long history of urban events that combine the culture of mass entertainment and the reorganization of cities. This type of international meeting attracts many visitors to a specific place. It is both a motive and catalyst for urban transformation and results in a unique urban development that would otherwise be very difficult to execute.

In Zaragoza, the intervention consisted of four main strategies. Firstly, the recovery of the river banks of the three rivers into a large axis of open spaces (more than fifty kilometres of new linear green areas) on an urban and territorial scale. Secondly, a better integration of the city was proposed through bridges and footbridges that connected previously isolated neighbourhoods. In addition, the Expo exhibition centre and the high-speed railway station were located on one of the meandering sections of the riverbank, near the city centre. Finally, service sector and culture clusters emerged linked to the opening of the Expo, with the aim of integrating the whole extension of this area. The Ebro River is undoubtedly the modifying and transforming agent of the complete transformation of Zaragoza (Fig. 7), which made possible the decentralization of the city's facilities, fostering a new urban balance.

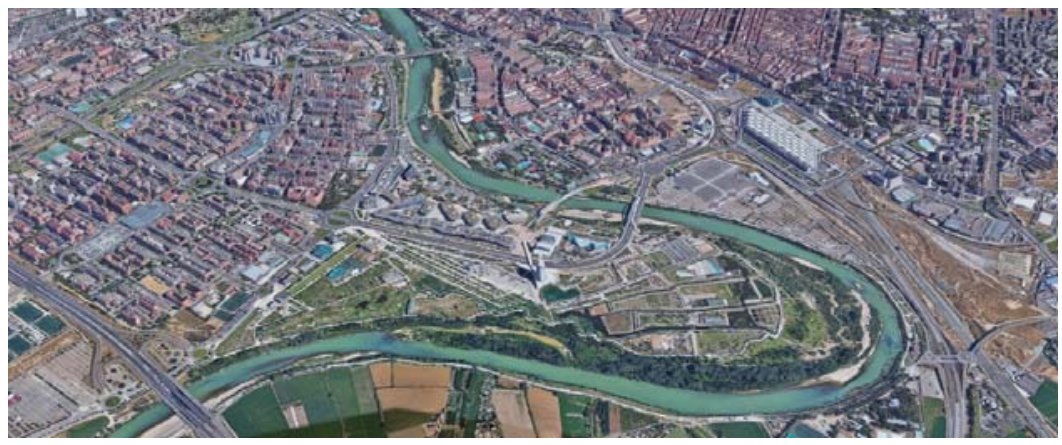

Figure 7: Aerial view Zaragoza Expo area. (Source: Google Earth.) 


\subsection{Bilbao}

The overall transformation of the city of Bilbao is probably one of the most interesting examples of a fluvial front regeneration in Spain. Bilbao, until recently, was an industrial city, characterized by an estuary that was used as a port infrastructure serving the steel industry located on the river banks. The steel industry crisis forced the transformation of metropolitan Bilbao, leading to a strategic project whose aim was to recover the estuary as a structuring element of the new Bilbao. The first step was to transfer the port activities in the estuary towards its mouth.

The name Bilbao Ría 2000 represents a conceptual leap whereby the estuary is considered as an urban structuring element through which the metropolitan territory is completely transformed. To this end, new infrastructures and buildings were proposed along the estuary banks. To integrate both banks of the estuary, as well as renewing old and obsolete industrial spaces, new low-level bridges were built providing accessibility to new tertiary sector areas and residential quarters promoted.

Apart from the construction of the new port of Bilbao, the first stage of the urban transformation took place in the Abandoibarra area, close to the nineteenth-century extension of the city, where the shipyards were located (Fig. 8). In fact, this regeneration of river banks is the new image of Bilbao and includes a transport infrastructure (new tramway) linear parks along the left bank and new bridges. The following facilities have had a very important role in the regeneration of Bilbao and are worthy of mention: public facilities (the Frank Gehry Guggenheim Bilbao Museum; Rafael Moneo's New Library of the University of Deusto; the University of the Basque Country Auditorium designed by Álvaro Siza); mixed spaces that combine commerce and residence (Isozaki Atea of Arata Isozaki; residential projected by Carlos Ferrater, César Portela and Robert Krier) and, tertiary sector buildings (Iberdrola Tower by the architect César Pelli), which is considered an urban landmark.

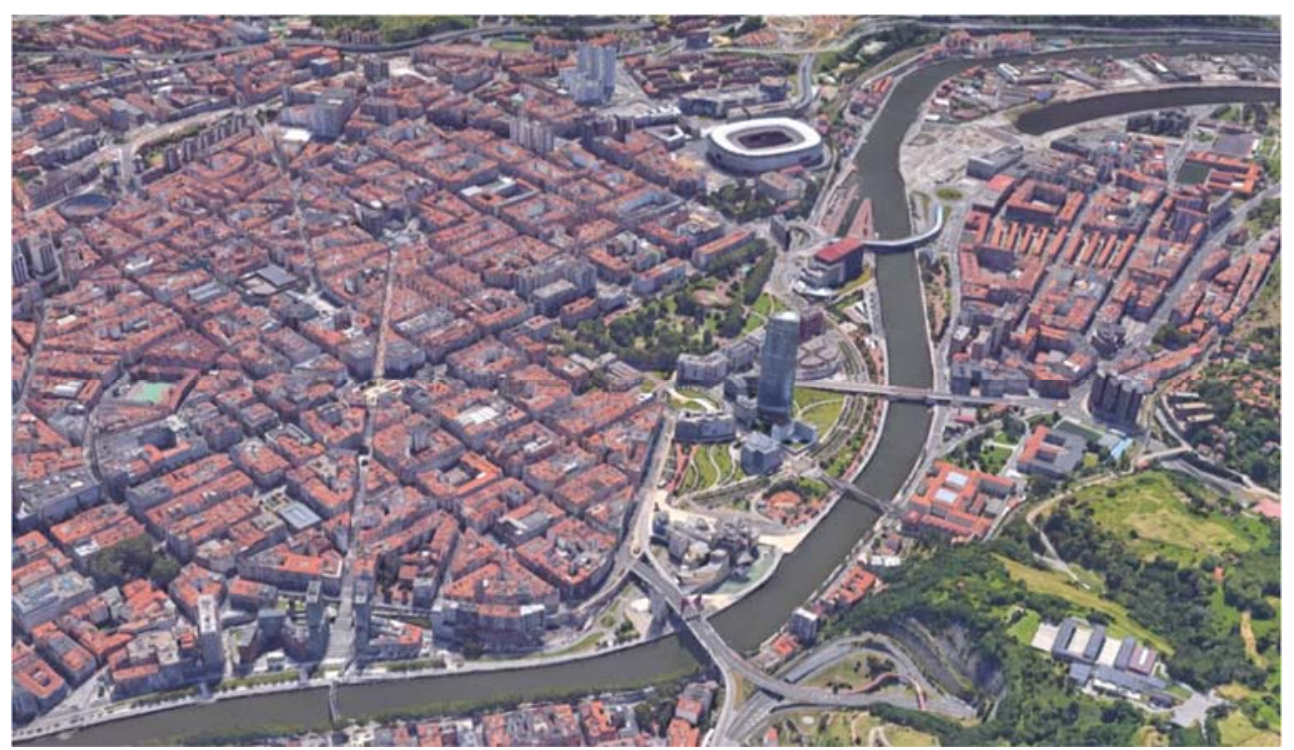

Figure 8: Bilbao. Aerial view of a stretch of the Ría area with the most relevant urban facilities. (Source: Google Earth.) 


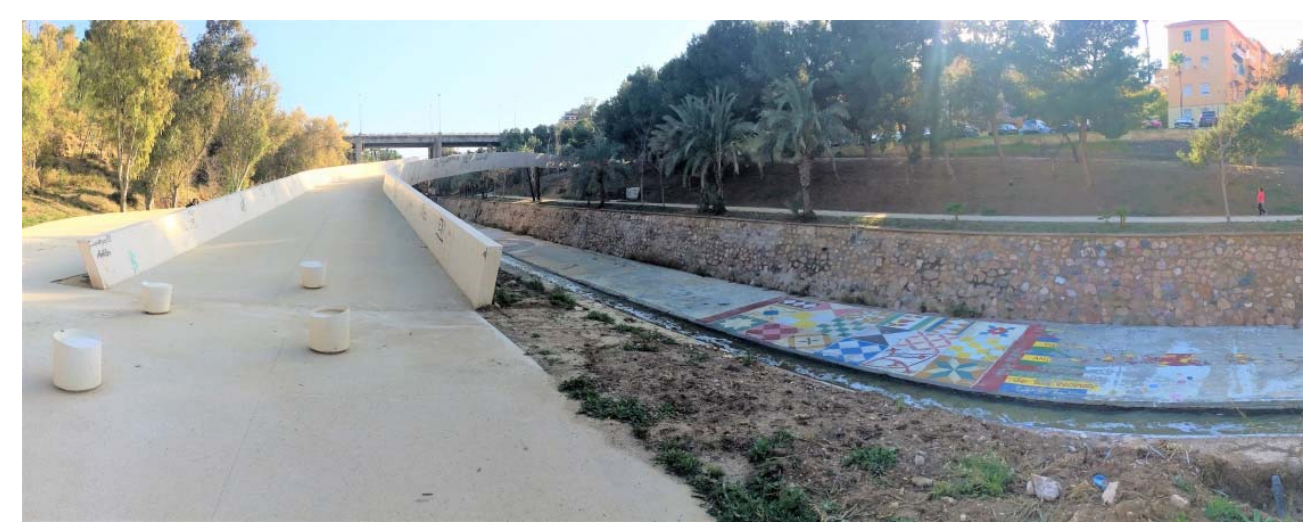

Figure 9: View of the intervention in the riverbed along the city of Elche. (Source: Author's image.)

\subsection{The Vinalopó River in Elche: the Braid Valley project.}

Elche's urban tissue is divided by the Vinalopó River, more accurately described as a ravine due to the scarcity of water and the narrow 40 -meter deep basin. Historically, several bridges and footbridges have linked the neighbourhoods on both sides of the ravine but these connections neither transformed the quality of the urban tissue nor provided access to the natural corridor. This site provided an opportunity for Elche to respond to citizen demands for a multipurpose public space with facilities in a very dense historical tissue of the city centre. For this reason, in 2008 the City Council held a contest for the best improvement and integration ideas for the Vinalopó River stretch in the City's area. The project presented by the multidisciplinary team Aranea won the contest [11].

The new design introduced innovative concepts into Elche's urban space, recovering some of the footprints of pedestrian traffic, which existed prior to the river channelling works in the 1970s. The final solution provided various routes for crossing the Vinalopó basin that improved accessibility with gentle slopes (Fig. 9). The native vegetation was reintroduced which gave new shaded paths. The improved environmental conditions offered a new site for open-air activities in the heart of the city along an 800-metre stretch of the $3 \mathrm{~km}$ originally planned [12].

\section{OTHER WATERFRONTS: WETLANDS}

The case of the Torrevieja lagoon is selected because it represents a different use of water resources in the territory. The landscape of two lagoons in a coastal territory was the place chosen for a Park of Relaxation designed by the Japanese architect Toyo Ito in 2000 (Fig. 10). A pleasant environment for taking thermal mud baths for medicinal purposes and enjoying the lagoon was proposed [13]. This project was part of an ambitious touristic excellence plan of city's council, including several proposals, that never was materialize.

\section{CONCLUSION}

The projects that combine water, architecture, and landscape in Spain are very recent, having been developed in the last thirty years. The social perception of water has changed completely: from a resource linked to industry and logistics to one providing cities, that have fluvial or maritime fronts, a new socially vibrant public space. 

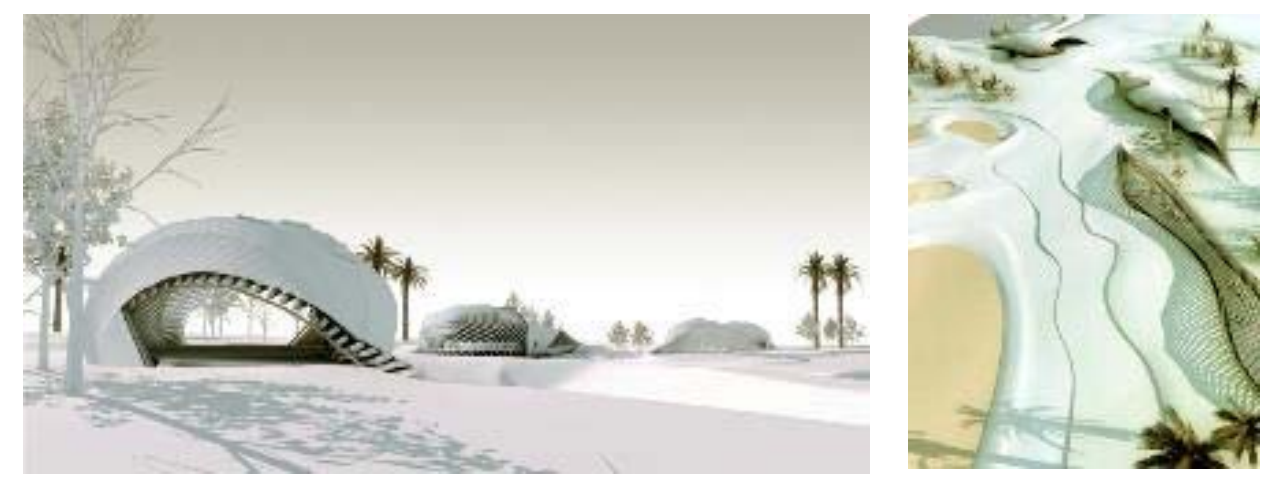

Figure 10: Lagoon project in Torrevieja (model pictures). (Source: Vía Arquitectura [14].)

Despite the relative recency of these water-linked interventions, they demonstrate the diversity of approaches and solutions. In each case, the main beneficiaries are locals and visitors. The architecture of these infrastructural spaces linked to water, among other things, spaces whose purpose is beyond a merely functional one. These transformations of urban contexts located at the edge of natural water landscapes offer a greater understanding of the territorial and urban space because they connect landscape features across different scales.

These renewal proposals have had a very positive social impact because they have enhanced the appreciation of these areas of the city and increased the economic value of residential and commercial property providing a multiscale global impact on the city.

\section{REFERENCES}

[1] Pozueta, J., Transformación de espacios portuarios en áreas urbanas. Urbanismo, 27, Colegio Oficial de Arquitectos de Madrid, pp. 6-17, 1996.

[2] Hall, P., Waterfronts: a New Urban Frontier, University of California, Berkeley, Institute of Urban and Regional Development.,Wp n ${ }^{\circ}$ 538, 1991.

[3] Ellen MacArthur Foundation, Cities in the Circular Economy: An Initial Exploration, Online. www.ellenmacarthurfoundation.org/assets/downloads/publications/Cities-inthe-CE_An-Initial-Exploration.pdf. Accessed on: 2 Dec. 2017.

[4] Clos, O., Del Moll de la Fusta. El Proyecto Urbano II/ UR Urbanismo Revista, 6, Laboratorio de Urbanismo, Escuela Técnica Superior de Arquitectura de Barcelona: Barcelona, 1988.

[5] Martorell, J. et al., Transformación de un frente marítimo. Barcelona. La Villa Olímpica, 1992, Editorial Gustavo Gili: Barcelona, 1988.

[6] Busquets, J., Barcelona. La Construcción Urbanistica de una Ciudad Compacta, Ediciones del Serbal: Barcelona, 2004.

[7] Pecourt, J. \& Piñón J.L., La Valencia Marítima del 2000, Colegio Oficial de Arquitectos de la Comunidad Valenciana: Valencia, 1997.

[8] Martí, P. \& Nolasco Cirugeda, A., El urbanismo y la urbanización del turismo in Canelobre, 66, Instituto Alicantino de Cultura Juan Gil Albert, Diputación de Alicante, pp. 146-155, 2016.

[9] Burgos, F. \& Garrido, G., Parque del río Manzanares, Madrid. Planur-e. Territorio, Urbanismo, Paisaje, Sostenibilidad y Diseño Urbano. Madrid, Summer 2017, Online. www.planur-e.es/miscelanea/view/parque-del-r-o-manzanares-madrid. Accessed on: 30 Sep. 2017. 
56 Urban Growth and the Circular Economy

[10] Gaja Díaz, F., La transformación de Valencia (II). Plan General de 1988: La última gran propuesta urbanística que ha dibujado el paisaje de la capital levantina. Revista Urbanismo COAM, 29, pp. 76-81, 1996.

[11] Maluenda, I.E. \& Encabo, E., El Valle Trenzado, Online. www.jesusgranada. com/valle trenzado. Accessed on: 10 Dec. 2017

[12] Rodríguez, F., Doce Paisajes. Arquitectura Viva, 184, pp. 13-40, 2016.

[13] Martí, P. \& Melgarejo, A., Arquitectura, agua y paisaje en algunas ciudades españolas. Agua, Arquitectura y Paisaje en Europa, Universidad de Alicante: Alicante, pp. 5977, 2015.

[14] Ito, T. \& Associates, Relaxation Park, Torrevieja, Alicante. Via Arquitectura, Online. https://www.via-arquitectura.net/17/112-017.htm. Accessed on: 2 Dec. 2017. 